\title{
RELATIONSHIP BETWEEN PHYSICAL AND CHEMICAL PROPERTIES OF ENTISOLS-FLUVENTS AND EROSION IN THE SÃO FRANCISCO RIVER ${ }^{1}$
}

\author{
RENISSON NEPONUCENO ARAÚJO FILHO ${ }^{2 *}$, FRANCISCO SANDRO RODRIGUES HOLANDA ${ }^{3}$, \\ MOACYR CUNHA FILHO ${ }^{4}$, VICTOR CASIMIRO PISCOYA ${ }^{5}$, JOSE DE OLIVEIRA MELO NETO ${ }^{2}$, \\ DANIELLE VIEIRA GUIMARÃES ${ }^{6}$
}

\begin{abstract}
The intense anthropization in the lower São Francisco River and surrounding areas can lead to environmental degradation risks and, above all, makes the area more susceptible to soil erosion. This study aimed to identify and correlate the physical and chemical properties able to enhance erosive processes and slope instability in the watercourse margins of the lower São Francisco River, in Sergipe State, Brazil. To this end, disturbed and undisturbed samples of an Entisol-Fluvent soil were collected in the region, specifically in the city of Amparo de São Francisco. Physical (density, porosity, and texture) and chemical ( $\mathrm{pH}$, cation exchange capacity, base saturation, micro-, and macronutrients) analyses were performed. All physical properties and organic carbon contents were higher in the surface layers (Ap and AC) compared to the others. Organic carbon, phosphorus, and micronutrients had a negative correlation with soil density, showing higher contents and lower soil densities in the Ap and AC layers. The pedological characteristics of the evaluated soil layers are unable to provide soil resistance to water erosion.
\end{abstract}

Keywords: Lower São Francisco River. Environmental degradation. Soil stability.

\section{RELAÇÕES ENTRE OS ATRIBUTOS FÍSICOS E QUIMICOS DO NEOSSOLO FLUVICO E OS PROCESSOS EROSIVOS NO RIO SÃO FRANCISCO}

\begin{abstract}
RESUMO - A intensa antropização no baixo do rio São Francisco e áreas adjacentes geram risco de degradação ambiental e, sobretudo, torna essa área mais suscetível a processos erosivos. O objetivo do estudo identificar e correlacionar os atributos físicos e químicos que potencializam os processos erosivos e estabilidade dos taludes em margens de curso de água no baixo curso do Rio São Francisco, estado Sergipe, Brasil. As amostras de solos deformada e indeformadas foram coletadas na região do Baixo rio São Francisco, município de Amparo de São Francisco, Sergipe, em Neossolo Flúvico. Foram realizadas análises físicas (densidade, porosidade e textura) e químicas ( $\mathrm{pH}$, Capacidade de Troca de Cátions, saturação por bases, micro e macronutrientes no solo). Os camadas superficiais (Ap e AC) apresentaram superiores atributos físicos e maior teor de carbono orgânico que os demais camadas. O carbono orgânico, fosfóro e os micronutrientes obtiveram correlação negativa com a densidade do solo, onde um maior teor destes elementos nos camadas Ap e AC resultam em menor densidade do solo. As caracteristicas pedologicas das camadas do perfil avaliado não proporcionam uma resistência a erosão hidrica.
\end{abstract}

Palavras-chave: Baixo Rio São Francisco. Degradação ambiental. Estabilidade do solo.

\footnotetext{
${ }^{*}$ Corresponding author

${ }^{1}$ Received for publication in 04/20/2020; accepted in 02/02/2021.

${ }^{2}$ Department of Forest Engineering, Universidade Federal do Tocantins, Gurupi, TO, Brazil; renisson@mail.uft.edu.br - ORCID: 00000002-9747-1276, jose.mneto@mail.uft.edu.br - ORCID: 0000-0001-7451-204X.

${ }^{3}$ Department of Agronomical Engineering, Universidade Federal de Sergipe, São Cristovão, SE, Brazil; fholanda@infonet.com.br ORCID: 0000-0001-6812-6679.

${ }^{4}$ Department of Statistics and Informatics, Universidade Federal Rural de Pernambuco, Recife, SE, Brazil; moacyr2006@gmail.com ORCID: 0000-0002-3466-8143.

${ }^{5}$ Department Rural Technology, Universidade Federal Rural de Pernambuco, Recife, SE, Brazil; victorcasimiropiscoya@gmail.com ORCID: 0000-0003-1875-9771.

${ }^{6}$ Department of Soil Science, Universidade Federal de Lavras, Lavras, MG, Brazil; danyvguimaraes@hotmail.com - ORCID: 0000-00032312-5968.
} 


\section{INTRODUCTION}

In recent years, several environmental impacts have been reported in the lower São Francisco River because of successive human interventions (HOLANDA et al., 2020a). The major environmental problem faced in this region is the erosion of the watercourse due to a development plan implemented. This has changed the chemical, physical, and biological balance due to the operation of large dams (ARAUJO FILHO et al., 2015; SANTOS et al., 2020b).

Hydrological regime control causes changes in the rise and stream velocity of watercourses, intensifying and accelerating erosion process (SANTOS et al., 2020a). Although expected, these changes interfere with the natural dynamics of the river, which may be resumed by adjusting the morphology of its channel (ROCHA et al., 2020). Such a situation can be enhanced or not by suppression of riparian vegetation (gallery forest) and constitutes a serious environmental degradation (HOLANDA et al., 2020b), given the exposure of unstable river embankments composed of lowcohesion soils (MACHADO et al., 2018).

Accelerated soil erosion can be mitigated by conservationist practices (ROCHA et al., 2018). These can be selected by the empirical knowledge of the occupation of the river banks by the local population aiming to protect them. Such alternatives may include the implementation of agro-ecosystems, engineering solutions, or even soil bioengineering (MOURA et al., 2017). Therefore, conservation planning and conservation practices can mitigate environmental disturbances caused either by natural means or by human actions (ARAUJO FILHO et al., 2017).

Using chemical soil properties as parameters in the study of soil quality plays an important role due to the low cost and fast methods, which allow a direct relationship with physical properties (ANDRADE et al., 2018). Knowing soil chemical properties such as acidity; contents of $\mathrm{Al}^{3+}, \mathrm{Ca}^{2+}$, $\mathrm{Mg}^{2+}, \mathrm{Na}^{+}, \mathrm{K}^{+}, \mathrm{P}, \mathrm{Fe}^{2+}, \mathrm{Cu}^{2+}, \mathrm{Mn}^{2+}$, and $\mathrm{Zn}^{2+}$; sum of bases (SB); cation exchange capacity (CEC); potential acidity $(\mathrm{H}+\mathrm{Al})$; and total organic carbon (TOC) (HOLANDA et al., 2017), in addition to their intrinsic relations, is of vital importance for a better understanding of erosion processes on slopes and for the generation of knowledge to increase their stability (MACHADO et al., 2015).

Thus, this study aimed to identify and correlate the physical and chemical properties able to enhance erosive processes and slope instability in the watercourse margins of the lower São Francisco River, in Sergipe State, Brazil

\section{MATERIAL AND METHODS}

\section{Study area}

Soil samples were collected on the slopes of the right embankment of the lower course of the São Francisco River. This is located in the city of Amparo de São Francisco, Sergipe, Brazil, at the geographical coordinates of $36^{\circ} 50^{\prime} 25.335^{\prime \prime} \mathrm{W}$ and $10^{\circ} 13^{\prime} 34.081^{\prime \prime} \mathrm{S}$ (Figure 1).
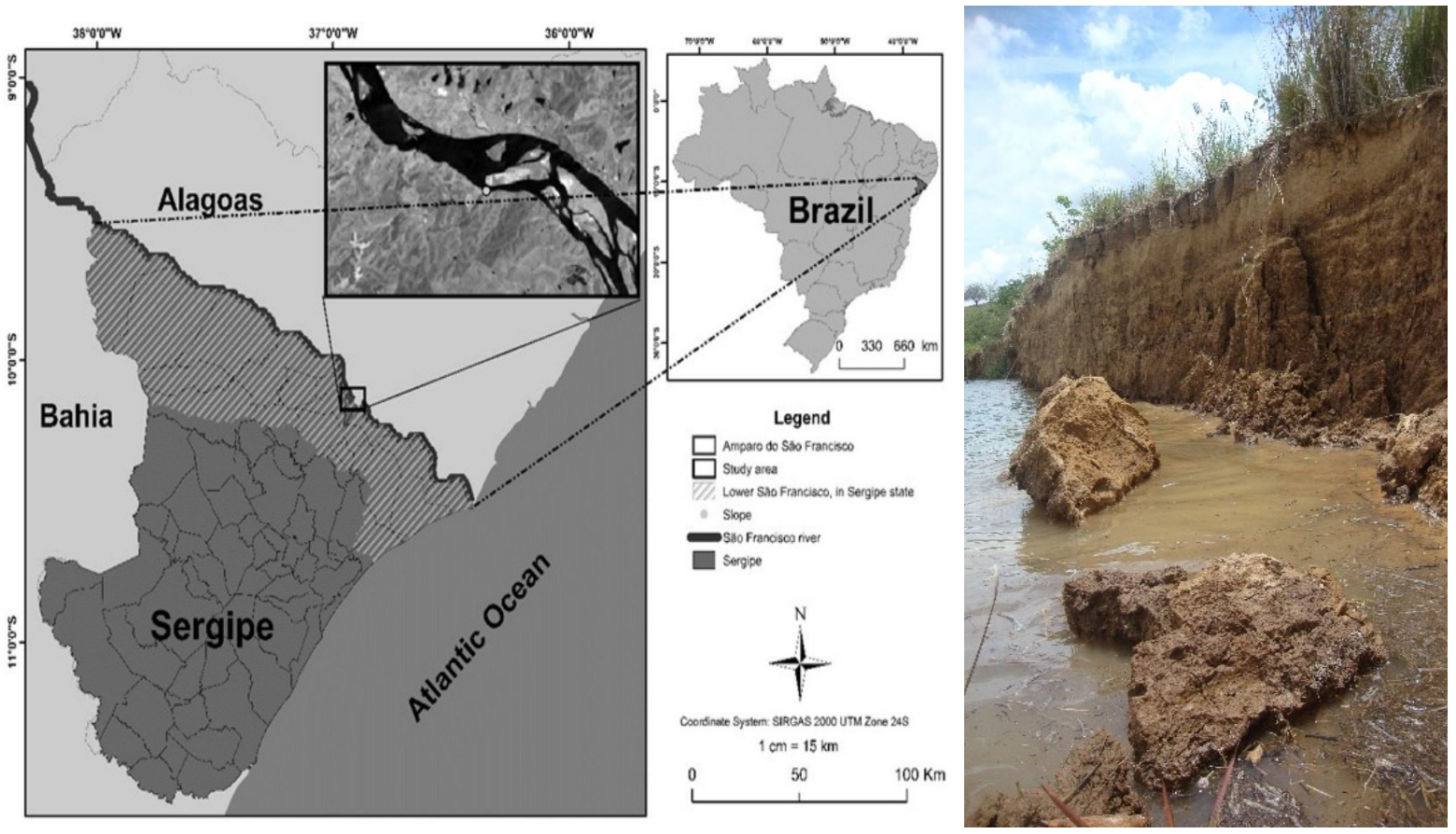

Figure 1. Location of the study area and profile, city of Amparo de São Francisco - SE (MACHADO et al., 2018). 
The soil in the experimental area is classified as Entisols Fluvents according to the Soil Taxonomy (SOIL SURVEY STAFF, 2014). The climate in the stretch of the San Francisco River with low sediment deposit is classified as Am type. This stands for humid and sub-humid megathermal climate, with an average temperature of $25^{\circ} \mathrm{C}$ and an annual average rainfall of $744.0 \mathrm{~mm}$ year $^{-1}$ (OLIVEIRA et al., 2019).

The experimental area was previously assessed for erosion process, soil physical properties (texture and structure), topographic data (height, slope, and slope length), vegetation absence, distance -to-thalweg (main channel) available for testing and access to the site. The slope of the embankment studied had the following dimensions: length of 100 $\mathrm{m}$ parallel to the slope, width of $15 \mathrm{~m}$, thus totaling a total area of $1,500.00 \mathrm{~m}^{2}$, average height of $6.00 \mathrm{~m}$, the average slope of $89.7 \%$, a mean water discharge of 2,557 $\mathrm{m}^{3} \mathrm{~s}^{-1}$ (ARAUJO FILHO et al., 2017).

\section{Soil Sample}

Morphological profile was described as recommendations of Santos et al. (2015). To this end, we used non-structured soil samples from six depth layers $(0.0-2.5,2.6-23.0,24.0-69.0,70.0-$ $109.0,110.0-153.0$, and $154.0-195.0 \mathrm{~cm}$ ) with five replicates equidistant 20 meters from each other, totaling 30 samples. These samples were collected by an 'Uhland' sampler, with dimensions $5 \times 5 \mathrm{~cm}$, placed in labeled plastic bags, and then assessed for soil bulk density.

\section{Soil physical and chemical analyses}

The physical properties assessed were soil bulk density (BD), total porosity (TP), particle density (PD), water dispersible clay (WDC), and dispersion index (DI). These were determined using the method developed by Teixeira et al. (2017). The chemical variables assessed were $\mathrm{pH}$ in $\mathrm{H}_{2} \mathrm{O}$; exchangeable $\mathrm{Al}^{3+}, \mathrm{Ca}^{2+}, \mathrm{Mg}^{2+}$; exchangeable $\mathrm{Al}^{3+}$, $\mathrm{Na}^{+}, \mathrm{K}^{+}$; potential acidity $(\mathrm{H}+\mathrm{Al})$; phosphorus $(\mathrm{P})$ content; sum of base (SB); effective cation exchange $(\mathrm{t})$; potential cation exchange $(\mathrm{T})$; base saturation (V); and contents of the micronutrients $\mathrm{S}, \mathrm{B}, \mathrm{Fe}, \mathrm{Cu}$, $\mathrm{Zn}$, and $\mathrm{Mn}$. These were also determined by a method developed by Teixeira et al. (2017). Finally, total organic carbon was assessed by a method adapted from Mendonca and Matos (2017).

\section{Statistical analysis}

A Pearson correlation was performed between physical and chemical properties using the Statistica 8.0 software (STATSOFT INC, 2008).

\section{RESULTS AND DISCUSSION}

The soil studied was classified as Entisols Fluvents Eutrophic Gley with a silt loam texture and was under a tropical deciduous forest and on a flat relief (SOIL SURVEY STAFF, 2014) (Table 1). The profile presented the following sequence of layers: Ap-Ac-C1-C2-C3-C4, among which Ap stands for a layer with changes by cultivation. The layer Ac has a rudimentary mineral deposit, poorly developed, and formed by recent alluvial deposits. Therefore, only this layer is classified as diagnostic and is followed by a succession of stratified layers, without any pedogenetic relationship and with different textural classes (FERRAZ et al., 2003).

Table 1. Morphological properties of the studied soil.

\begin{tabular}{|c|c|c|c|c|c|c|c|c|}
\hline \multirow{2}{*}{ Layer } & \multirow{2}{*}{$\begin{array}{l}\text { Depth } \\
(\mathrm{cm})\end{array}$} & \multicolumn{2}{|c|}{ Color } & \multirow{2}{*}{ Structure } & \multicolumn{3}{|c|}{ Consistency } & \multirow{2}{*}{ Transition } \\
\hline & & Moist & Dry & & Dry & Moist & Wet & \\
\hline Ap & $0-2.5$ & $10 \mathrm{YR}^{3} / 4$ & - & $12 \mathrm{Gr}$ & - & $\mathrm{MFr}$ & - & $\mathrm{cp}$ \\
\hline $\mathrm{AC}$ & $2.6-23$ & $10 \mathrm{YR}^{3} / 4$ & - & $23 \mathrm{Bls} \mathrm{M}$ & MD & - & LgPlPe & $\mathrm{gc}$ \\
\hline $\mathrm{C} 1$ & $24-69$ & $10 \mathrm{YR}^{4} / 4$ & - & 2 Bls M & - & $\mathrm{Fr}$ & LgPIPe & $\mathrm{pc}$ \\
\hline $\mathrm{C} 2$ & 70-109 & $7.5 \mathrm{YR}^{4} / 4$ & - & $2 \mathrm{Bls}$ & - & $\mathrm{Fr}$ & LgPIPe & $\mathrm{pc}$ \\
\hline $\mathrm{C} 3$ & $110-153$ & $5 \mathrm{YR}^{4} / 4$ & - & $12 \mathrm{Bls} \mathrm{P}$ & - & - & LgPlPe & $\mathrm{pd}$ \\
\hline $\mathrm{C} 4$ & 154-195 & $10 \mathrm{YR}^{4} / 6$ & - & $12 \mathrm{Bls} \mathrm{P}$ & - & - & $\mathrm{Pe}$ & - \\
\hline
\end{tabular}

Structure: 1 - weak; 2 - moderate; 3 - strong; MP - very small; P - small; M - mean; Gr - granular; Bls - subangular blocks; Mc - massive; MoC: moderately cohesive. Consistency: LD - slightly hard; D - hard; MD - very hard; MFr - very friable; Fr - friable; Fi - firm; Lg - slightly; Pl - plastic; Pe - sticky. Transition: p - plane; g - gradual; d - diffuse; c - clear.

Soil color ranged from brown to dark yellowish brown in surface and subsurface, with 10YR hue in sub-surface and dark brown (with values 3 and chromas 3, moist color) in Ap and Ac horizons, which is due to organic material accumulation. The $\mathrm{C} 2$ layer presented a brown color (7.5YR 4/4) with common and small mottled zones, with a distinct and bluish gray color. The color of the 
layer C3 was classified as reddish brown (5YR 4/4), reflecting the reduction in carbon levels therein. Moreover, this horizon has a poorly developed thickness, less than 1-m depth (Table 1).

After the Ap layer, the soil structure was a weak-to-moderate single aggregate due to land use conditions. The degree of development in the AC layer was low throughout the entire profile, with no diagnostic layer and little differentiation between layers (Table 1). Soil structure is related to the degree of stability of soil aggregates. It can be classified as poor, moderate, or strong depending on the bond strength between the aggregates. In general, the lower the degree of soil development, the greater its erodibility. This is because poorly developed soils are more susceptible to raindrop impact given a smaller contact area between particles, thus facilitating particle detachment (MOURA et al., 2017).

A cohesive character was identified in the soil by structure and consistency tests (Table 1).
Cohesion is a force that binds particles together both within and between aggregates (UCGUL; FIELKE; SAUNDERS, 2015). In the lower São Francisco, river flow regularization causes changes in river dimensions and flow speeds, which intensify and accelerate erosion process, enhanced or not by riparian vegetation removal. As a result, serious environmental degradation can occur due to exposure of unstable riverbanks, which comprise low -cohesion soils (MACHADO et al., 2018).

Vegetation plays an important role in erosion control in river banks since grasses and herbs provide offer the most efficient protection to soils (JOTISANKASA; SIRIRATTANACHAT，2017). Furthermore, the vegetation root system increases soil water infiltration, cohesion, and resistance (VANNOPPEN et al, 2017).

In general, the clay fraction of the soil varied as a function of depth since sandy clay. Sand fraction predominates in the deeper layers of the slope, close to the water level (Table 2).

Table 2. Averages of soil physical properties.

\begin{tabular}{|c|c|c|c|c|c|c|c|c|c|c|}
\hline \multirow{2}{*}{ Layer } & Coarse Sand & Fine Sand & Total Sand & Silt & Clay & WDC & $\mathrm{BD}$ & $\mathrm{PD}$ & $\mathrm{TP}$ & DI \\
\hline & \multicolumn{6}{|c|}{-------------------------------g kg } & \multicolumn{2}{|c|}{$--\mathrm{g} \mathrm{cm}^{-3}--$} & $\%$ & \\
\hline Ap & 94.48 & 119.84 & 214.31 & 249.89 & 535.80 & 452.52 & 1.48 & 2.43 & 39.01 & 0.84456 \\
\hline $\mathrm{AC}$ & 100.53 & 89.76 & 190.29 & 249.71 & 559.99 & 414.43 & 1.55 & 2.46 & 36.95 & 0.74007 \\
\hline $\mathrm{C} 1$ & 100.37 & 169.59 & 269.96 & 229.94 & 500.10 & 0.16 & 1.64 & 2.50 & 34.46 & 0.00032 \\
\hline $\mathrm{C} 2$ & 100.46 & 69.85 & 170.31 & 259.92 & 569.77 & 0.19 & 1.68 & 2.47 & 32.25 & 0.00035 \\
\hline $\mathrm{C} 3$ & 100.39 & 159.95 & 260.34 & 239.78 & 499.88 & 0.13 & 1.75 & 2.43 & 28.07 & 0.00027 \\
\hline $\mathrm{C} 4$ & 1.20 & 609.39 & 610.59 & 139.65 & 249.77 & 0.09 & 1.75 & 2.47 & 29.25 & 0.00040 \\
\hline
\end{tabular}

WDC - Water Dispersed Clay; BD - Bulk Density; PD - Particle Density; TP - Total porosity; DI - Dispersion Index.

Poorly stable aggregates, mainly in lower layers, have a positive correlation with erodibility in the river banks. For Othman, Megdiche and Gueddari (2016), sandy soils have a larger number of voids, i.e., greater macroporosity, due to low activity of cementing agents that form low-stability aggregates.

The layers Ap and AC showed higher averages of WDC and DI, which decreased in depth. This high clay dispersion must have been due to an excess of electronegative charges in the soil arising from organic matter constituents (VAN DEN BOGAERT; LABILLE; CORNU, 2015). In a study by Gao et al. (2015), organic acids of low molecular weight increased the amount of dispersed clay. In agreement with these studies, Table 3 shows the high contents of organic matter in the soil (SOM) in the layers Ap and AC, which may explain the high WDC and DI values compared to those in subsurface layers (Table 6).

BD ranged from 1.48 to $1.75 \mathrm{~g} \mathrm{~cm}^{-3}$ in the studied soil profile, increasing with depth (Table 2). In sandy soils, BD usually varies from 1.2 to $1.8 \mathrm{~g} \mathrm{~cm}^{3}$, while in loamy soils from 1.0 to $1.6 \mathrm{~g} \mathrm{~cm}^{3}$ (BRADY; WEIL, 2007). This is probably due to lower organic matter contents, less particle aggregation, absence of roots, and less thickening due to pressure exerted by the upper layers (CARVALHO et al., 2017). Erosion resistance may increase or decrease depending on the soil density (LI et al., 2017).

Total porosity ranged from 29.25 to $39.01 \%$ (Table 2). The soils with lower porosity have low penetration values, which directly affect gas exchange in the soil profile and vegetation development due to resistance against root growth. Therefore, there is a greater concentration of roots in the superficial layers of the soil (HOLANDA et al., 2017).

Averages of all basic exchangeable cations were higher in the Ap layer, influencing sum of bases (Table 3 ). 
Table 3. Averages of soil chemical properties.

\begin{tabular}{|c|c|c|c|c|c|c|c|c|c|c|c|c|}
\hline Layer & $\mathrm{Ca}$ & $\mathrm{Mg}$ & $\mathrm{K}$ & $\mathrm{Na}$ & $\mathrm{Al}$ & $\mathrm{H}+\mathrm{Al}$ & $\mathrm{BS}$ & $\mathrm{t}$ & $\mathrm{T}$ & $\mathrm{m}$ & $\mathrm{V}$ & SOM \\
\hline & & \multicolumn{8}{|c|}{ 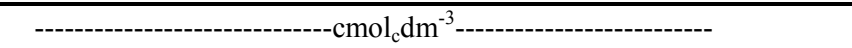 } & \multicolumn{2}{|c|}{------\%"----- } & $\mathrm{g} \mathrm{kg}^{-1}$ \\
\hline Ap & 8.14 & 4.00 & 1.31 & 0.12 & 0.00 & 2.60 & 13.57 & 13.57 & 16.17 & 0.00 & 83.92 & 11.99 \\
\hline $\mathrm{AC}$ & 4.70 & 3.06 & 1.55 & 0.16 & 0.00 & 2.60 & 9.46 & 9.46 & 12.06 & 0.00 & 78.44 & 3.31 \\
\hline $\mathrm{C} 1$ & 4.14 & 2.62 & 1.01 & 0.24 & 2.14 & 5.60 & 8.01 & 10.15 & 13.61 & 21.07 & 58.85 & 1.37 \\
\hline $\mathrm{C} 2$ & 5.10 & 3.08 & 0.51 & 0.07 & 2.90 & 8.72 & 8.77 & 11.67 & 17.49 & 24.87 & 50.12 & 1.20 \\
\hline $\mathrm{C} 3$ & 5.16 & 3.58 & 0.23 & 0.04 & 1.02 & 3.92 & 9.01 & 10.03 & 12.93 & 10.18 & 69.67 & 1.17 \\
\hline $\mathrm{C} 4$ & 2.30 & 1.94 & 0.04 & 0.02 & 0.00 & 1.20 & 4.30 & 4.30 & 5.50 & 0.00 & 78.17 & 0.32 \\
\hline
\end{tabular}

Organic acids were responsible for mobilization or complexation of cations by raising the $\mathrm{pH}$ and neutralizing aluminum (VIRTO et al., 2018). However, Oerter et al. (2014) reported that the interrelationships among $\mathrm{K}, \mathrm{Ca}$, and $\mathrm{Mg}$ should be considered in the dynamics of ion exchange in the soils. This is because the excess of one ion can interfere with the others, and thus directly influence chemical processes in the soil. Moreover, the excess of $\mathrm{Na}$ and $\mathrm{K}$ may favor dispersion of clay particles due to its inverse relationship when compared to divalent cations, in terms of flocculation of soil colloids (HUANG et al., 2016).

Table 4. Averages of soil chemical properties.
Both effective CEC (t) and CEC pH7 (T) were predominantly high throughout the soil profile, except in the layer C4 (Table 3). This may have been due to clay and organic carbon activities in the soil so that the presence of SOM tends to increase CEC (CARDOSO et al., 2011). Aluminum content increased in deeper layers, particularly in $\mathrm{C} 1$ and $\mathrm{C} 2$ (Table 3), with similar results for aluminum saturation, reflecting the lower $\mathrm{pH}$ in these layers. The profile presented $\mathrm{pH}$ reaction acid in strongly acidic water, indicating the smaller values $\mathrm{C} 1$ and $\mathrm{C} 2$ are layers as noted in Table 4.

\begin{tabular}{cccc}
\hline Layer & $\mathrm{pH}$ & $\mathrm{P}$ & $\mathrm{C}$ \\
\hline & & $\mathrm{mg} \mathrm{kg}^{-1}$ & $\mathrm{~g} \mathrm{~kg}^{-1}$ \\
\hline $\mathrm{Ap}$ & 6.14 & 92.00 & 6.96 \\
$\mathrm{AC}$ & 6.16 & 10.60 & 1.92 \\
$\mathrm{C} 1$ & 5.20 & 2.32 & 0.80 \\
$\mathrm{C} 2$ & 4.80 & 1.00 & 0.70 \\
$\mathrm{C} 3$ & 5.22 & 1.96 & 0.68 \\
$\mathrm{C} 4$ & 6.30 & 2.88 & 0.19 \\
\hline
\end{tabular}

This acidification was caused by lower levels of exchangeable bases and organic compounds in the soil exchange complex. Exchanging hydrogen ions or complexing calcium, aluminum, magnesium, potassium, and other organic fractions favors an increase in $\mathrm{pH}$, the contrary, in turn, may reduce $\mathrm{pH}$ (AMARAL; ANGHINONI; DESCHAMPS, 2004).

Phosphorus showed low values in the layers $\mathrm{C} 1, \mathrm{C} 2, \mathrm{C} 3$, and $\mathrm{C} 4$. This may have been due to lower $\mathrm{pH}$ and soil exchangeable bases (Table 4). Soil $\mathrm{P}$ dynamics has a close relationship with the chemical, physical, and biological properties of the soil (FINK et al., 2016). Mineral clay particles have a larger number of anion adsorption sites due to their increased specific surface area, which gives the soil a greater capacity to adsorb P. High levels of aluminum and iron oxides increase $\mathrm{P}$ adsorption capacity, making it unavailable in the soil solution (FANG et al., 2017).

Organic carbon contents ranged from 0.19 to
$6.96 \mathrm{~g} \mathrm{~kg}^{-1}$ (Table 4). In the layers $\mathrm{Ap}$ and Ac, additional increases of organic carbon in the soil may have occurred due to higher inputs of organic material. Increases in organic carbon in the soil are due to supply of organic matter such as senescent biomass components above and below the soil, leaf fall, waste from cropping operations, dead animals, and respective decomposition rates (ANDRADE et al. 2018).

In general, higher amounts of micronutrients were observed in the upper layers (Table 5). Micronutrients such as $\mathrm{Zn}, \mathrm{Cu}, \mathrm{Fe}$, and $\mathrm{Mn}$ participate in several key metabolic activities in plants (BEZERRA; ARAÚJO; MIRANDA, 2012). Their availability is affected by an increase in soil $\mathrm{pH}$, a decrease in organic matter content, sandy soil textures, mineralization and immobilization thereof by microorganisms, and oxi-reduction potential under high oxidation conditions (SANTOS et al., 2015). 
Table 5. Averages of micronutrients in the soil.

\begin{tabular}{|c|c|c|c|c|}
\hline Layer & $\mathrm{Zn}$ & $\mathrm{Cu}$ & $\mathrm{Mn}$ & $\mathrm{Fe}$ \\
\hline & \multicolumn{4}{|c|}{ 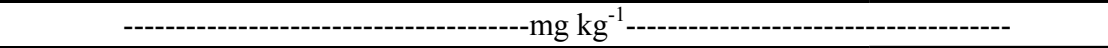 } \\
\hline Ap & 11.09 & 8.11 & 83.09 & 285.35 \\
\hline $\mathrm{AC}$ & 4.92 & 4.72 & 3.61 & 121.49 \\
\hline $\mathrm{C} 1$ & 4.32 & 3.52 & 24.30 & 103.71 \\
\hline $\mathrm{C} 2$ & 4.61 & 4.00 & 26.18 & 103.72 \\
\hline $\mathrm{C} 3$ & 4.31 & 3.10 & 26.02 & 83.76 \\
\hline $\mathrm{C} 4$ & 4.12 & 2.61 & 11.60 & 23.71 \\
\hline
\end{tabular}

The cations $\mathrm{Ca}, \mathrm{Mg}, \mathrm{K}, \mathrm{Na}$, and $\mathrm{Al}$ showed positive correlations, from weak to strong, with coarse sand, silt, and clay. The opposite was observed concerning total sand and fine sand, which had a negative correlation as shown in Table 6.

As clays have a greater specific surface area, high reactivity and negative electrical charges increase cation adsorption onto colloidal surfaces. These cations bond to clays forming cationic bridges, which are important for the stability and formation of aggregates. These, in turn, provide greater resistance to soil erosion (ZHUA et al., 2016). Clay minerals are generally of pedogenic origin, that is, formed by recrystallization atoms resulting from the dismantling of mineral origin sources. Thus, clay minerals have a greater number of imperfections, creating more negative electrical charges. On the other hand, coarse silt and sand fractions have little influence on total charges in the soil since these fractions have no charges (SHARMA et al., 2015).

Table 6. Coefficient of linear correlation (r) between soil chemical and physical properties.

\begin{tabular}{cccccccccccc}
\hline Variable & $\mathrm{Ca}^{1}$ & $\mathrm{Mg}^{1}$ & $\mathrm{~K}^{1}$ & $\mathrm{Na}^{1}$ & $\mathrm{Al}^{1}$ & $\mathrm{H}+\mathrm{Al}^{11}$ & $\mathrm{BS}^{1}$ & $\mathrm{t}^{1}$ & $\mathrm{~T}^{1}$ & $\mathrm{~m}^{1}$ & $\mathrm{~V}^{1}$ \\
\hline Grit & $0.62^{* * *}$ & $0.70^{* * *}$ & $0.57^{* *}$ & $0.52^{* *}$ & $0.42^{*}$ & $0.54^{* *}$ & $0.70^{* * *}$ & $0.84^{* * *}$ & $0.85^{* * *}$ & $0.43^{* *}$ & -0.34 \\
Fine Sand & $-0.68^{* * *}$ & $-0.73^{* * *}$ & $-0.62^{* * *}$ & $-0.47^{* *}$ & $-0.39^{*}$ & $-0.56^{* *}$ & $-0.75^{* * *}$ & $-0.88^{* * *}$ & $-0.90^{* * *}$ & $-0.39^{*}$ & 0.32 \\
Sand Total & $-0.69^{* * *}$ & $-0.73^{* * *}$ & $-0.62^{* * *}$ & $-0.46^{*}$ & $-0.38^{*}$ & $-0.56^{* *}$ & $-0.76^{* * *}$ & $-0.88^{* * *}$ & $-0.90^{* * *}$ & $-0.37^{*}$ & 0.31 \\
Silt & $0.72^{* * *}$ & $0.77^{* * *}$ & $0.59^{* * *}$ & $0.41^{*}$ & $0.38^{*}$ & $0.56^{* *}$ & $0.78^{* * *}$ & $0.90^{* * *}$ & $0.92^{* * *}$ & $0.37^{*}$ & -0.31 \\
Clay & $0.68^{* * *}$ & $0.72^{* * *}$ & $0.64^{* * *}$ & $0.48^{* *}$ & $0.38^{*}$ & $0.56^{* *}$ & $0.75^{* * *}$ & $0.88^{* * *}$ & $0.90^{* * *}$ & $0.37^{*}$ & -0.31 \\
WDC & $0.65^{* * *}$ & $0.54^{* *}$ & $0.82^{* * *}$ & 0.27 & $-0.62^{* * *}$ & $-0.43^{*}$ & $0.72^{* * *}$ & $0.44^{*}$ & 0.24 & $-0.64^{* * *}$ & $0.68^{* * *}$ \\
BD & $-0.72^{* * *}$ & $-0.54^{* *}$ & $-0.90^{* * *}$ & $-0.56^{* *}$ & 0.31 & 0.15 & $-0.79^{* * *}$ & $-0.63^{* * *}$ & $-0.47^{* *}$ & 0.32 & $-0.40^{*}$ \\
\hline
\end{tabular}

${ }^{1}$ Number of observations $(\mathrm{n})=25$.WDC - Water Dispersed Clay; BD - Bulk Density. Significant $\mathrm{P}<0.05^{*}, \mathrm{P}<0.01^{* *}$, and $\mathrm{P}<$ $0.001^{* * *}$.

Except for $\mathrm{Al}$, WDC showed positive correlations with $\mathrm{Ca}, \mathrm{Mg}, \mathrm{K}$, and $\mathrm{Na}$ contents (Table 6). The cations $\mathrm{Ca}, \mathrm{Mg}, \mathrm{K}$, and $\mathrm{Na}$ increase clay dispersion in the soil as their contents are increased flocculants and $\mathrm{Al}$ are removed, thus promoting dispersion. Clay dispersion can lead to clogging of soil pores (FARAHANI et al., 2018), hindering gas exchanges and water infiltration, as well as plant root development. Additionally, $\mathrm{Al}^{3+}$ reduces the thickness of the diffuse double layer of colloids with variable electric charges (CORASSA et al., 2016), and when $\mathrm{Al}$ is replaced with $\mathrm{Ca}, \mathrm{Mg}, \mathrm{K}$, and $\mathrm{Na}$, the thickness of the diffuse double layer of colloids increases due to replacement of a flocculating ion with a less flocculating one, resulting in dispersion.

$\mathrm{BD}$ had negative correlations with $\mathrm{Ca}, \mathrm{Mg}, \mathrm{K}$, and $\mathrm{Na}$ (Table 6) due to its increasing effect on a diffuse double layer, so that soil dispersion and disaggregation occurs, thus interfering with its structure and hence its BD. Soil dispersion or aggregation varies with electrolyte concentrations and cation valence. In general, polyvalent cations favor aggregation by forming cation bridges with negatively charged particles (MATOS; ALMEIDA NETO; MATOS, 2014).

The results presented in Table 7 highlight a moderate negative correlation between $\mathrm{pH}$ and soil density.

As the concentrations of exchangeable bases increase in the soil, its $\mathrm{pH}$, dispersion, and density increase. According to Bayabil et al. (2015), soil pH reduction raises negative charges on the surface of clay particles, which subsequently induces soil dispersion for an increase in repulsion between clay particles, soil structural deterioration, blocking of larger pores (hydraulically active), decreasing soil permeability, and thus increasing BD.

$P$ content showed a strong negative correlation with soil density (Table 7). Increases in P content by adsorption on clay fraction particles affected soil dispersion, reducing its density. The adsorption of $\mathrm{P}$ on clay fraction surface increases its electronegativity, promoting electrostatic repulsion between particles and soil disaggregation (FINK et 
al., 2016). Under the studied soil $\mathrm{pH}$ conditions, $\mathrm{P}$ predominates because it corresponds to $\mathrm{H} 2 \mathrm{PO} 4-$ equilibrium reactions in soil (SILVA; SILVA;
PEREIRA, 2011), so adsorption occurs by connecting negative charges of phosphate ion with positive charges.

Table 7. Coefficients of linear correlation (r) among pH, carbon content, sulfur, and soil physical properties.

\begin{tabular}{cccc}
\hline Variable & $\mathrm{pH}^{1}$ & $\mathrm{P}^{1}$ & $\mathrm{C}^{1}$ \\
\hline Grit & $-0.52^{* *}$ & 0.15 & 0.26 \\
Fine Sand & $0.48^{* *}$ & -0.22 & -0.34 \\
Sand Total & $0.46^{*}$ & -0.23 & -0.35 \\
Silt & $-0.46^{*}$ & 0.22 & 0.34 \\
Clay & $-0.48^{* *}$ & 0.25 & $0.36^{*}$ \\
WDC & $0.61^{* * *}$ & $0.75^{* * *}$ & $0.82^{* * *}$ \\
BD & $-0.37^{*}$ & $-0.77^{* * *}$ & $-0.84^{* * *}$ \\
\hline
\end{tabular}

${ }^{1}$ Number of observations $(\mathrm{n})=25$.WDC - Water Dispersed Clay; BD - Bulk Density. Significant $\mathrm{P}<0.05^{*}, \mathrm{P}<0.01^{* *}$, and $\mathrm{P}<$ $0.001^{* * *}$.

The effect of $\mathrm{C}$ on soil physical properties showed a strong positive correlation with dispersion but negative with soil density (Table 7). Carbon may affect soil dispersion through sorption of organic anions by aggregates. This promotes adsorption on the surface of negatively charged colloids, increasing the formation of organic complexes with di- and trivalent ions and reducing the ionic strength of the solution. Diffused layer increases and soil dispersion occurs (AHMAD et al., 2014). In several models for estimating soil density, organic carbon is considered an important predictor due to the high correlation between C and BD (CARVALHO JUNIOR, et al., 2016), as can be seen in this study.

A strong positive correlation was observed between micronutrients $(\mathrm{Zn}, \mathrm{Cu}$, and $\mathrm{Fe})$ and clay dispersed in water (Table 8).

Table 8. Coefficients of linear correlation (r) between micronutrients and soil physical properties.

\begin{tabular}{ccccc}
\hline Variable & $\mathrm{Zn}^{1}$ & $\mathrm{Cu}^{1}$ & $\mathrm{Mn}^{1}$ & $\mathrm{Fe}^{1}$ \\
\hline Grit $\left(\mathrm{g} \mathrm{kg}^{-1}\right)$ & 0.20 & $0.37^{*}$ & 0.25 & $0.48^{* *}$ \\
Fine Sand $\left(\mathrm{g} \mathrm{kg}^{-1}\right)$ & -0.27 & $-0.46^{* *}$ & -0.28 & $-0.55^{* *}$ \\
Sand Total $\left(\mathrm{g} \mathrm{kg}^{-1}\right)$ & -0.29 & $-0.48^{* *}$ & -0.29 & $-0.56^{* *}$ \\
Silt $\left(\mathrm{g} \mathrm{kg}^{-1}\right)$ & 0.31 & $0.49^{* *}$ & 0.33 & $0.57^{* * *}$ \\
Clay $\left(\mathrm{g} \mathrm{kg}^{-1}\right)$ & 0.28 & $0.48^{* *}$ & 0.27 & $0.55^{* *}$ \\
WDC $\left(\mathrm{g} \mathrm{kg}^{-1}\right)$ & $0.75^{* * *}$ & $0.85^{* * *}$ & $0.46^{* *}$ & $0.78^{* * *}$ \\
BD $\left(\mathrm{g} \mathrm{cm}^{-3}\right)$ & $-0.77^{* * *}$ & $-0.89^{* * *}$ & $-0.57^{* *}$ & $-0.86^{* * *}$ \\
\hline
\end{tabular}

${ }^{1}$ Number of observations (n) $=25$. WDC: Water Dispersed Clay; BD: Bulk Density. Significant $\mathrm{P}<0.05^{*}, \mathrm{P}<0.01^{* *}$, and $\mathrm{P}$ $<0.001^{* * * *}$.

According to Araújo Filho et al. (2015), high Fe concentrations cause clay dispersion due to their coating, changing their charges. $\mathrm{Zn}$ and $\mathrm{Cu}$ are strongly retained in the solid soil matrix, which is altered by rearrangement of particles resulting from elution by water infiltration when the soil presents greater dispersion of particles. In this sense, natural porosity becomes obstructed by illuviated clay particles, which leads to an increase in soil density (SPERA et al., 2008), which explains the inverse relationship between micronutrients and BD.

\section{CONCLUSIONS}

Surface layers (Ap and AC) showed better physical properties and higher organic carbon contents than the others. Organic carbon, phosphorus, and micronutrients showed a negative correlation with soil bulk density; therefore, higher contents of these elements in the layers Ap and AC result in lower soil bulk densities. The characteristics of the evaluated soil layers do not provide soil resistance to water erosion. 


\section{REFERENCES}

AHMAD, M. et al. Biochar as a sorbent for contaminant management in soil and water: a review. Chemosphere, 99: 19-33, 2014.

AMARAL, A. S.; ANGHINONI, I.; DESCHAMPS, F. C. Resíduos de plantas de cobertura e mobilidade dos produtos da dissolução do calcário aplicado na superfície do solo. Revista Brasileira de Ciência do Solo, 28: 115-123, 2004.

ANDRADE, K. V. S. et al. Mangrove soil in physiographic zones in the estuary of Sao Francisco River. Floram, 25: 1-9, 2018.

ARAÚJO FILHO, R. N. et al. Influência dos atributos físico-mecânicos do solo na estabilidade do talude do rio São Francisco. Scientia Agraria, 18: 107-113, 2017.

ARAÚJO FILHO, R. N. et al. Efficiency of Simple Super Phosphate in the vetiver grass development subjected to soil bioengineering. Revista Caatinga, 28: 86-97, 2015.

BAYABIL, H. K. et al. Assessing the potential of biochar and charcoal to improve soil hydraulic properties in the humid Ethiopian Highlands: The Anjeni watershed. Geoderma, 243-244: 115-123, 2015.

BEZERRA, V. C. G.; ARAÚJO, C. W. N.; MIRANDA, C. B. Potencial de fertilizantes e corretivos no aporte de micronutrientes ao solo. Revista Brasileira de Ciência do Solo, 36: 931-938, 2012.

BRADY, N.; WEIL, R. R. The Nature and Properties of Soils. 14 ed. Prentice Hall, 2007. 980 p.

CARDOSO, A. I. I. et al. Alterações em propriedades do solo adubado com composto orgânico e efeito na qualidade das sementes de alface. Horticultura Brasileira, 29: 594-599, 2011.

CARVALHO JUNIOR, W. et al. Regressão linear múltipla e modelo Random Forest para estimar a densidade do solo em áreas montanhosas. Pesquisa Agropecuária Brasileira, 51: 1428-1437, 2016.

CARVALHO, D. C. et al. Estoque de Carbono e Nitrogênio e Abundância Natural de $\delta 13 \mathrm{C}$ na Estação Ecológica de Pirapitinga, MG. Floresta Ambiente, 24: 2-10, 2017.
CORASSA, G. M. et al. Espacialização em alta resolução de atributos da acidez de Latossolo por meio de sensoriamento em tempo real. Pesquisa Agropecuária Brasileira, 51: 1306-1316, 2016.

FANG, H. et al. Phosphorus adsorption onto clay minerals and iron oxide with consideration of heterogeneous particle morphology. Science of the Total Environment, 605: 357-367, 2017.

FARAHANI, E. et al. Impact of monovalent cations on soil structure. International Agrophysics, 32: 57 65, 2018.

FERRAZ, R. P. D. et al. Diagnóstico do Meio Físico da Bacia Hidrográfica do Rio do Imbé RJ: Aplicação de Metodologia Integrada como Subsídio ao Manejo de Microbacias. 1. ed. Rio de Janeiro, RJ: EMBRAPA, 2003. 90 p.

FINK, J. R. et al. Adsorption and desorption of phosphorus in subtropical soils as affected by management system and mineralogy. Soil and Tillage Research, 155: 62-68, 2016.

GAO, Y. et al. Low-molecular-weight organic acids influence the sorption of phenanthrene by different soil particle size fractions. Journal of Environmental Quality, 44: 219-227, 2015.

HOLANDA, F. S. R. et al. Biotechnical potential of Paspalum submitted to simple superphosphate doses and moisture content. Scientia Agraria, 18: 43-49, 2017.

HOLANDA, F. S. R. et al. Formação de ondas e os processos erosivos nas margens do lago da UHE Xingó. Revista Brasileira de Geografia Física, 13: 887-902, 2020a.

HOLANDA, F. S. R. et al. Degradation of geotextiles of Typha latifolia Linn used in soil bioengineering techniques. Ciência Florestal, 30: 1148-1160, 2020b.

HUANG, L. M. et al. Pedogenesis significantly decreases the stability of water-dispersible soil colloids in a humid tropical region. Geoderma, 274: 45-53, 2016.

JOTISANKASA, A.; SIRIRATTANACHAT, T. Effects of grass roots on soil-water retention curve and permeability function. Canadian Geotechnical Journal, 54: 1612-1622, 2017.

LI, Q. et al. Relative contribution of root physical enlacing and biochemistrical exudates to soil erosion 
resistance in the Loess soil. Catena, 153: 61-65, 2017.

MOURA, M. M. et al. Estimativa de perda de solo no Baixo São Francisco sergipano. Scientia Agraria, 18: 126-135, 2017.

MACHADO, L. et al. Effect of vetiver roots on soil resistance to penetration in a typic fluvic neossol in the São Francisco riverbank. Revista Caatinga, 31: 935-943, 2018.

MACHADO, L. et al. Contribution of the root system of vetiver grass towards slope stabilization of the São Francisco River. Semina, 36: 2453-2463, 2015.

MATOS, A. T.; ALMEIDA NETO, O. B.; MATOS, M. P. Saturação do complexo de troca de solos oxídicos com sódio. Revista brasileira de Engenharia Agrícola e Ambiental, 18: 501-506, 2014.

MENDONÇA, E. S.; MATOS, E. S. Matéria orgânica do solo: métodos de análises. 2. ed. Viçosa, MG: UFV, 2017. 221 p.

MOURA, M. M. et al. Estimativa de perda de solo no baixo São Francisco sergipano. Scientia Agraria, 18: 126-135, 2017.

OERTER, E. et al. Oxygen isotope fractionation effects in soil water via interaction with cations $(\mathrm{Mg}$, $\mathrm{Ca}, \mathrm{K}, \mathrm{Na}$ ) adsorbed to phyllosilicate clay minerals. Journal of Hydrology, 515: 1-9, 2014.

OLIVEIRA, T. S. et al. Litter production in mangrove forests of the estuary São Francisco river. Floresta, 49: 813-820, 2019.

OTHMAN, D. B.; MEGDICHE, M. F.; GUEDDARI, M. Contribution to the determination of the hydraulic conductivity in the saturation of soil. Arabian Journal of Geosciences, 9: 57- 65, 2016.

ROCHA, I. P. et al. Magnitude and Spatiotemporal Variation of the Erosion on the Slope of the Lower São Francisco River, Northeastern Brazil. Journal of Experimental Agriculture International, 24: 1-11, 2018.

ROCHA, I. P. et al. Direct Shear Strength on the São Francisco River Bank, Northeastern Brazil, With or Without Roots of Different Native Species. Journal of Agricultural Studies, 9: 146-172, 2020.

SANTOS, B. B. C. et al. Micronutrient contents of a revegetated saprolite exposed by excavation of an oxisol. Communications in Soil Science and Plant Analysis, 46: 283-295, 2015.

SANTOS, M. H. et al. Macrophytes communities associated to soil bioengineering techniques for erosion control in riverbanks. Iheringia. Série Botânica, 75: 1-7, 2020a.

SANTOS, M. S. et al. Perception about technological, sustainable and environmental indicators of the lower SÃO FRANCISCO/SE. Revista INGI-Indicação Geográfica e Inovação, 4: 595-606, 2020b.

SHARMA, A. et al. Characterizing soils via portable $\mathrm{X}$-ray fluorescence spectrometer: 4. Cation exchange capacity (CEC). Geoderma, 239: 130-134, 2015.

SILVA, J. T. A.; SILVA, I. P.; PEREIRA, R. D. Adubação fosfatada em mudas de bananeira 'Prata anã'(AAB), cultivadas em dois Latossolos. Revista Ceres, 58: 238-242, 2011.

SOIL SURVEY STAFF. Keys to Soil Taxonomy. 12. ed. Washington, DC: USDA, 2014. 300 p.

SPERA, S. T. et al. Dispersão de argila em microagregados de solo incubado com calcário. Revista Brasileira de Ciência do Solo, 32: 2613 2620, 2008

STATSOFT INC. Statistica data analysis system version 8.0. Tulsa: Statsoft Inc., 2008.

TEIXEIRA, P. C. et al. Manual de métodos de análise do solo. 3. ed. Brasilia, DF: EMBRAPA, 2017. $573 \mathrm{p}$

UCGUL, M.; FIELKE, J. M.; SAUNDERS, C. Three -dimensional discrete element modelling (DEM) of tillage: Accounting for soil cohesion and adhesion. Biosystems Engineering, 129: 298-306, 2015.

VAN DEN BOGAERT, R.; LABILLE, J.; CORNU, S. Aggregation and dispersion behavior in the 0-to 2$\mu \mathrm{m}$ fraction of Luvisols. Soil Science Society of America Journal, 79: 43-54, 2015.

VANNOPPEN, W. et al. How do root and soil characteristics affect the erosion-reducing potential of plant species? Ecological Engineering, 109: 186195,2017

VIRTO, I. et al. Role of Carbonates in the Physical Stabilization of Soil Organic Matter in Agricultural Mediterranean Soils. In: Muñoz, M.Á.; Zornoza, R. (Eds.). Soil Management and Climate Change. London, UK: Academic Press, 2018. v. 12, cap. 9, p.121-136. 
ZHUA, F. et al. Aging of bauxite residue in association of regeneration: a comparisonof methods to determine aggregate stability \& erosion resistance.

Ecological Engineering, 92: 47-54, 2016. 